\title{
ESTABLISHING A COORDINATION SYSTEM FOR CONSTRUCTION PROJECT ORGANIZATIONS BY SIMULATING HUMAN BODY CIRCULATORY SYSTEM
}

\author{
Fang-Ying SHEN, Andrew S. CHANG \\ Department of Civil Engineering, National Cheng Kung University, No. 1, University Road, \\ Tainan City 701, Taiwan
}

Received 22 Jul. 2011; accepted 10 Nov. 2011

\begin{abstract}
Construction projects are highly fragmented with many participants and activities involved during construction, so coordination is complicated and critical for project organizations. The physiological functions of the human body such as the circulatory system are natural and effective. This study established a coordination system for construction projects by simulating the circulatory system to improve work effectiveness. The contractor has to coordinate the owner and suppliers, that is, like the heart does to the brain and various organs. A procedure was also developed and illustrated through a case study to use the system practically. The contractor engineer acting as a receptor evaluates coordination needs derived from project uncertainty and equivocality and collect time spent on coordination with various parties. Coordination time or amount is adjusted when coordination supply does not meet needs. This procedure can be applied on construction project organizations to plan and execute coordination work.

Keywords: coordination system; circulatory system; coordination needs and supply; construction projects.

Reference to this paper should be made as follows: Shen, F.-Y.; Chang, A. S. 2013. Establishing a coordination system for construction project organizations by simulating human body circulatory system, Journal of Civil Engineering and Management 19(4): 492-504. http://dx.doi.org/10.3846/13923730.2013.768543
\end{abstract}

\section{Introduction}

Coordination is a central purpose of organizations (Okhuysen, Bechky 2009) and has been regarded as a critical factor for construction projects (Jha, Iyer 2006; Yang et al. 2009). Coordination can be seen as the process of managing dependencies among activities and linking together different parts of an organization to accomplish a collective set of tasks (Malone, Crowston 1994). Because construction projects are highly specialized and involve many parties, they are prone to a great deal of uncertainty, and coordination between project participants is complicated. However, project participants coordinate their work using methods such as meetings, plans, and contract documents out of convenience or preference rather than effectiveness (Carlson, Davis 1998). They even do not adjust coordination frequency or time to the project nature and conditions. Because of this, although time and money are spent on coordination, project performance often does not meet expectations.

The physiological functions of the human body are natural and effective. Researchers have tried to mimic the functions of the human body to improve work effectiveness. The artificial neural network is an example of a successful case. The human body is a network of systems, including the circulatory system, digestive system, respiratory system, etc., which are composed of groups of organs with a common function or set of functions, all of which are mutually dependent. The circulatory system transports nutrients to various organs through blood flow and reacts to environmental changes to maintain homeostasis.

During the construction stage, a contractor has to continuously coordinate work with relevant parties to move the project forward and must adjust the content and frequency of coordination methods in response to changes, such as changes in design or site conditions. The function of project coordination, which is to process and transmit information between the contractor and other parties, is similar to that of the circulatory system of the human body. It seems that the operation of circulatory system can be simulated and applied to construction project coordination. 
Coordination is important and complicated for construction projects, so a systematic method for participants to coordinate work efficiently and effectively is essential. The purpose of this paper is to establish a coordination system for construction projects that simulates the circulatory system. A procedure for effective coordination in construction projects was presented accordingly to use the coordination system practically. The applicability of the proposed system and the procedure was illustrated through a case study. The coordination system and procedure could help construction project organizations plan and execute coordination work more systematically and effectively due to natural and effective physiological functions of the human body being applied.

\section{Literature review}

Previous research on effective coordination in the management and construction fields can be grouped into two categories: choice of coordination methods and the relationship between coordination and project performance. The theories used in, and conclusions reached by, these studies are discussed below.

\subsection{Choice of coordination methods}

Coordination methods consist of meetings, face-toface and telephone discussions, site visits, written correspondence, plans, schedules, reports, and contract documents (ASCE 2000; Chang, Shen 2009). These methods have different information processing capabilities, which make them more or less effective in various dimensions (Zack 1993; Wiesenfeld et al. 1999).

Several theories have been addressed to explain how different coordination methods are used. Daft and Lengel (1986) proposed the media richness theory (MRT), which characterizes communication media as being high or low in richness based on feedback, multiple cues, language variety, and personal focus. Face-to-face discussion is considered to be the richest communication medium for it allows for rapid feedback, multiple cues (such as head nods, smiles, eye contact, etc.), and gets personal attention. Rules are the lowest in richness. A communication medium with high richness is suitable for use on highly equivocal tasks, whereas those with low richness are used for highly uncertain tasks. Moreover, symbolic cues carried by methods, such as formality and urgency, also influence users' choices (Webster, Trevino 1995).

On the basis of MRT, Dennis et al. (2008) and Carlson and Zmud (1999) proposed the media synchronicity theory (MST) and channel expansion theory, respectively. In addition to feedback, cues, and personal attention, MST incorporates rehearsability and reprocessability, which represent the infor- mation processing capabilities of communicators. The channel expansion theory argues that the perceived richness of a medium depends not only on its characteristics, but also on users' experiences including timing, who they communicate with, the nature of the task, and the organizational context.

Kock's (2004) psychobiological model, based on Darwin's theory of evolution, argues that humans have evolved to favor face-to-face communication and proposes the idea of naturalness, which is the degree to which a method is similar to face-to-face communication. The lower the naturalness of a method, the greater the cognitive effort required to use it.

In the construction field, recent coordination studies focused on information technology in order to control information flow especially at the design stage. For example, the electronic document management systems could keep control of design activities and contain enhanced features related to the life cycle, revision history, and version management (Gabrielaitis, Baušys 2006). Building information models have been applied in constructability analyses, design checks, and supporting decisions and improving processes throughout the life cycle of a project (Leite et al. 2011). However, project participants at the construction stage coordinate their work using methods such as meetings, plans, and contract documents as mentioned above more often than electronic methods (Adriaanse et al. 2010).

Based on the information-processing (IP) model, the IP capability of an organization should fulfill its IP requirements (Daft, Lengel 1986). IP requirements are created by uncertainty and equivocality, coming from task characteristics, task interdependence, human characteristics, task environment, and task-possessed information (Chang 2001). IP capacity refers to the time engineers spend on external and internal communication, as well as internal work. Chang (2001) concluded that tasks with a good fit between capacity and requirements had good cost performance. Chang and Shen (2009) examined coordination supply and the needs of subway projects. They concluded that projects that performed well used adequate oral or written coordination methods that were based mainly on work equivocality.

\subsection{Relationship between coordination and project performance}

A number of studies have examined relationships between coordination and project performance. Pocock et al. (1996) identified that projects with more interaction between designers and contractors had better cost and schedule performance, but project performance did not appear to improve significantly beyond a certain degree of interaction. Thomas et al. (1998) indicated that $41 \%$ of successful projects resulted from effective communication. Patrashkova-Volzdoska 
et al. (2003) investigated 60 cross-functional project teams and found that communication frequency was curvilinearly related to team performance, meaning that increased coordination did not necessarily result in better performance, and could actually impede it. Enshassi et al. (2009) investigated factors affecting the performance of construction projects, and the result indicated that coordination between owner and parties is considered important by owners, consults, and contractors.

As mentioned above, effective coordination is beneficial to construction project performance that allots adequate communication time and employs appropriate methods for different requirements. However, most studies are descriptive or lacking empirical investigation. Their results only identified phenomena that could not solve real problems, such as overuse of written correspondence and longer than necessary plans for construction projects (Shen 2009).

\section{Coordination system compared with circulatory system}

To enhance coordination among construction project organizations, the coordination system was established by simulating the circulatory system and is depicted in Figure 1.

The circulatory system, including the heart, blood vessels, and blood, serves the function of transportation. Blood carries oxygen and substances essential for cellular metabolism to cells and removes waste products to help maintain homeostasis, which is the existence and maintenance of a relatively constant environment within the body. The way that the circulatory system functions as presented in Figure 1 can be divided into three parts: resting state, monitor- ing mechanism, and regulation mechanism (Seeley et al. 2003; Sherwood 2007).

A project organization is like a human body; project participants are similar to different organs; coordination between participants resembles the functions of blood vessels and blood. The way the circulatory system operates can be applied to normal coordination, monitoring, and regulation of coordination work. A more detailed understanding of the relationships is explained as follows.

\subsection{Entity and function comparison}

Construction project participants can be compared to different organs according to their roles and functions as shown in Table 1. The contractor who functions as the heart of a project is a key to success. He/she is responsible for project coordination and integration and therefore has to communicate with relevant parties including the owner, internal members, subcontractors, and suppliers. The contractor also needs to adjust coordination frequency or goals when accidents occur, like the heart regulates blood flow. For example, when a project is delayed because of a subcontractor's inability to finish a task, the contractor can hold meetings to find a solution or ask the subcontractor to propose acceleration plans.

The owner is like the brain. The owner, responsible for overseeing the contractor, gets information from plans submitted by the contractor or through visiting the site to ensure that the project is implemented according to the terms of the contract. When a condition emerges in a project or the contractor violates the contract, the owner can force the contractor to fix defects and help get the project on track. This is similar to the role of the central nervous system regulating blood flow.

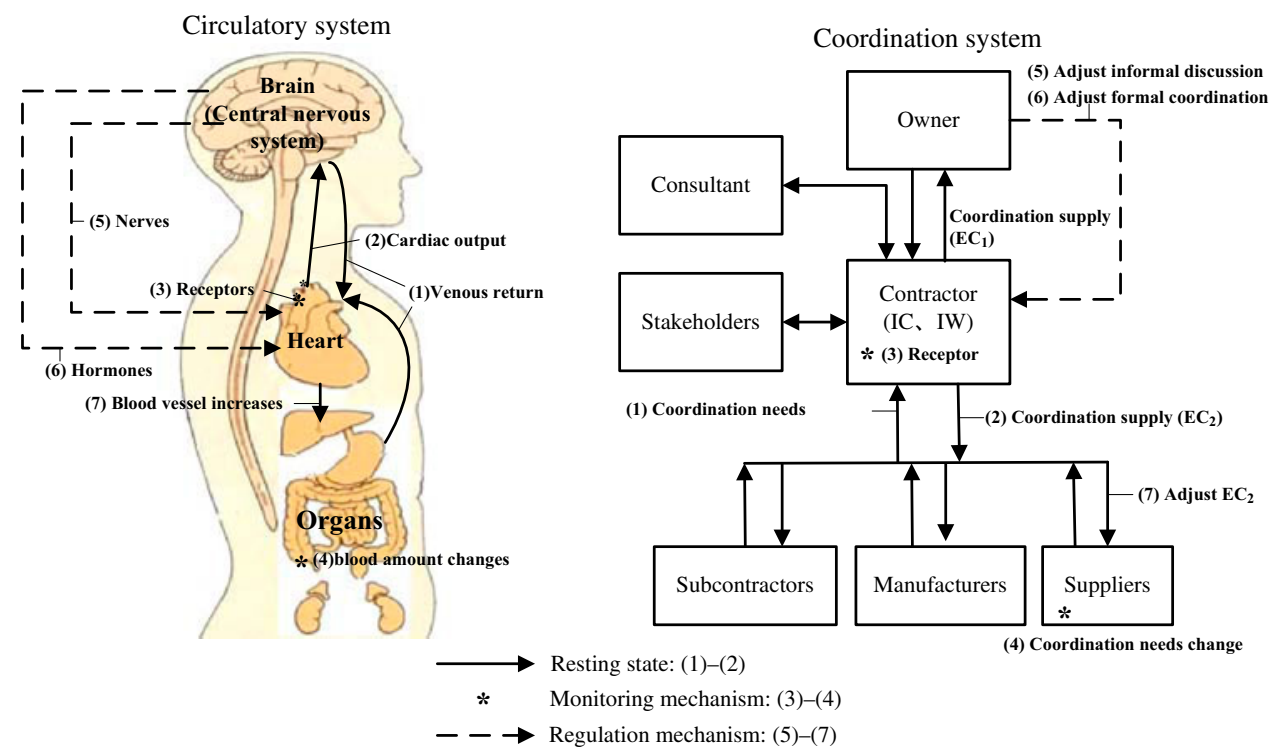

Fig. 1. Comparisons between circulatory system and coordination system 
Table 1. Entity and function comparisons between coordination system and circulatory system

\begin{tabular}{lll}
\hline Item & \multicolumn{1}{c}{ Circulatory system } & \multicolumn{1}{c}{ Coordination system } \\
\hline Entity & 1. Heart & 1. Contractor \\
& 2. Brain (central nervous system) & 2. Owner \\
3. Organs & 3. Subcontractors, suppliers \\
4. Blood & 4. Information \\
& 5. Blood vessels & 5. Coordination methods \\
& 6. Blood flow & 6. Coordination time or frequency \\
& 7. Cardiac output & 7. Coordination supply \\
& 8. Venous return & 8. Coordination needs \\
\hline
\end{tabular}

Subcontractors and suppliers are like the various organs. They do work by following instructions from the contractor, like organs receive blood from the heart. For instance, steel and concrete subcontractors may be compared to the stomach and intestines. Their work to transfer construction materials into engineering projects for building is similar to the ingestion and digestion of food and absorption of nutrients. Moreover, tile and plastering subcontractors, who work on smooth building surfaces and waterproofing, are like the skin that protects the body.

Regarding functional comparisons, information and coordination methods have the same functions as blood and blood vessels. Information to be passed between the contractor and relevant parties is transmitted using tools, and coordination methods, such as meetings and plans, serve this function. Additionally, when a party requires more information, the duration or frequency of coordination may be increased. The cardiac output and venous return represent the body's total blood supply and requirements, which can be compared to the total coordination supply and needs of a project. Coordination needs refer to the amount of coordination required for a project, and coordination supply refers to the amount of coordination supplied by the project participants. In this study, time spent on coordination methods was used to evaluate the amount of coordination.

\subsection{Operation comparison}

The operation of the coordination system includes normal coordination, monitoring, and regulation through simulation of the circulatory system. Operation comparisons of the two systems are presented in Figure 1 and Table 2:

(1) Normal coordination. For the circulatory system, when the body is at rest, blood flows from the heart (cardiac output) to all organs in various amounts based on metabolic requirements and returns to the heart (venous return) constantly. Project participants with different needs coordinate work with each other through coordination methods. The total coordination needs of a project are constant. Coordination supplied by the contractor should meet parties' needs so that tasks can be done well. Too much or too little coordination impedes project performance because of waste or lack of information, respectively (Lengel, Daft 1989; Forrester, Drexler 1999).

As item 1 of Figure 1 and Table 2 shows, the blood requirements of organs are different at different times, and coordination needs of the contractor and relevant parties for each project vary as well. For construction projects, coordination needs are created by uncertainty and equivocality (U\&E) (Chang, Shen 2009). Uncertainty includes the absence of information that allows workers to predict what may happen (Daft 2004). It can be reduced through the acquisition of data, followed by analysis and the writing of plans and reports. Equivocality, or ambiguity, is the existence of multiple and conflicting interpretations (Daft, Macintosh 1981). Engineers can exchange opinions, clarify ambiguities, define problems, and reach agreements to reduce equivocality.

The coordination needs of the contractor can be divided into the following categories: coordination with the owner or other stakeholders $\left(\mathrm{EC}_{1}\right)$, internal coordination (IC), coordination with subcontractors $\left(\mathrm{EC}_{2}\right)$, and internal work (IW) according to engineers' work mechanisms (Chang 2001; Chang, Shen 2009). The needs of $\mathrm{EC}_{1}, \mathrm{IC}$, and $\mathrm{EC}_{2}$ are created by equivocality and can be reduced primarily through interacting with people, such as meetings and telephone discussions. IW includes jobs that engineers do work alone, without interacting with people, such as analyzing data and writing reports. The coordination need of $\mathrm{EC}_{1}$ is like the blood flow that the brain requires for operation; the coordination need of $\mathrm{EC}_{2}$ is similar to the blood flow that other organs need to function; the coordination needs of IC and IW can be compared to the blood flow, which the heart requires to operate normally.

Coordination is supplied to reduce U\&E through various methods (item 2). Chang and Shen (2009) categorized nine coordination methods used on construction projects, which were further subcategorized into oral and written coordination as shown in Figure 2. Oral coordination consists of meetings, telephone, face-to-face discussions, and site visits; written 
Table 2. Operation comparisons of coordination system and circulatory system

\begin{tabular}{|c|c|c|}
\hline Mechanisms & Circulatory system & Coordination system \\
\hline Normal coordination & $\begin{array}{l}\text { 1. Venous return results from blood } \\
\text { requirements of organs } \\
\text { 2. Cardiac output is determined by venous } \\
\text { return }\end{array}$ & $\begin{array}{l}\text { Coordination needs result from } \mathrm{U} \& \mathrm{E} \text { and are divided } \\
\text { into } \mathrm{EC}_{1}, \mathrm{IC}, \mathrm{EC}_{2} \text {, and IW } \\
\text { Coordination is supplied through coordination } \\
\text { methods based on needs of } \mathrm{EC}_{1}, \mathrm{IC}, \mathrm{EC}_{2} \text {, and IW }\end{array}$ \\
\hline Monitoring & $\begin{array}{l}\text { 3. Receptors monitor blood pressure } \\
\text { continually and inform the central nervous } \\
\text { system } \\
\text { 4. Blood requirement of organs varies with } \\
\text { environmental changes }\end{array}$ & $\begin{array}{l}\text { A receptor assigned by the contractor evaluates the } \\
\text { balance between coordination needs and supply } \\
\text { Subcontractors realize their needs change as design } \\
\text { change or accidents occur }\end{array}$ \\
\hline Regulation & $\begin{array}{l}\text { 5. Nervous reaction: the heart is asked to } \\
\text { increase or decrease blood flow through } \\
\text { nerves } \\
\text { 6. Hormonal reaction: the heart is asked to } \\
\text { increase cardiac output through hormones } \\
\text { chronically } \\
7 \text {. Vessel expansion: blood flow raises as } \\
\text { organ vessels increase }\end{array}$ & $\begin{array}{l}\text { Informal coordination: the contractor increases } \\
\text { coordination time through informal methods because } \\
\text { of an emergent condition } \\
\text { Formal coordination: when planned coordination } \\
\text { supply doesn't meet needs, it is regulated such as } \\
\text { revising plans and more meetings } \\
\text { EC }_{2} \text { adjustment: When the } \mathrm{EC}_{2} \text { need changes, } \\
\text { subcontractors should inform the contractor }\end{array}$ \\
\hline
\end{tabular}

coordination includes written correspondence, plans, schedules, reports, and contract documents.

Figure 2 also illustrates the relationships between the nine coordination methods and four needs. The contractor can interact with relevant parties directly through meetings, which are helpful for clarifying problems and making decisions, and satisfy owner's $\left(\mathrm{EC}_{1}\right)$, subcontractors' $\left(\mathrm{EC}_{2}\right)$, and internal (IC) coordination needs. Telephone and face-to-face discussions can be used to fulfill the needs of $\mathrm{EC}_{1}$, IC, or $\mathrm{EC}_{2}$ depending on parties with whom the contractor mainly coordinates. Though decisions made through the two informal methods cannot be enforced, they can supplement normal coordination methods because of their timeliness.

There are three kinds of site visits: visits with the owner, visits with subcontractors, and solo visits that are labeled $\mathrm{EC}_{1}, \mathrm{EC}_{2}$, and IW. Site visits with the owner can be used to help the owner understand site conditions, clarify drawings or specifications, or ask the contractor to fix defects. They are helpful to reducing equivocality $\left(\mathrm{EC}_{1}\right)$. The goals of site visits with subcontractors include material inspections, understanding work results, and providing instruc-

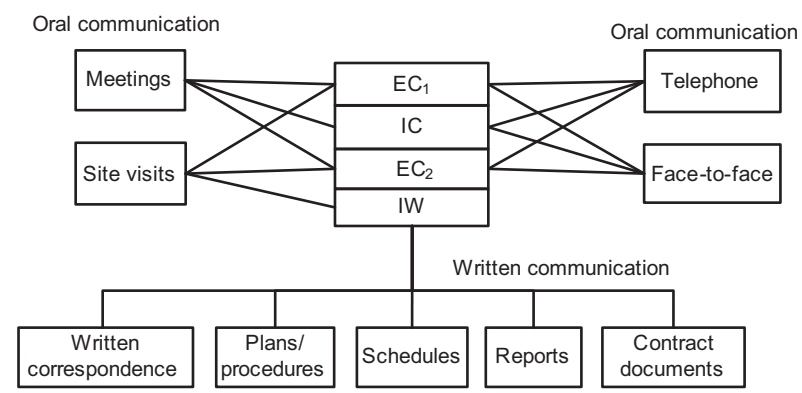

Fig. 2. Relationships between coordination needs and methods tions, which all can fulfill the $\mathrm{EC}_{2}$ need. In addition, site engineers often visit sites alone to check project progress or construction quality every day, whereas project managers and other engineers only visit the site while necessary. During solo visits, contractor engineers spend most of their time on collecting information related to work results or progress even though they may talk with subcontractors occasionally. Hence solo visits mainly help reduce uncertainty and is classified as IW.

The five written methods help increase information and are all linked to IW. The correspondence that engineers write after collecting and organizing information, or receiving letters from other parties, helps to increase information. When writing and using plans, schedules, and reports, engineers need to gather and process information. Moreover, contract documents reviewed and appended by engineers to ensure that obligations and responsibilities are fulfilled during the construction stage satisfy the IW need.

(2) Monitoring. The coordination needs of a project organization vary according to the environment, the same as the blood requirements of the body do. In response to environmental changes, the heart monitors blood pressure and organs detect blood insufficiency. During construction, as the internal or external environment changes because of events such as accidents or design changes, coordination needs change accordingly. For example, the collapse of neighboring buildings results in a greater need for coordination between the contractor and residents $\left(\mathrm{EC}_{1}\right)$. Schedule delays caused by poor execution on the part of subcontractors increases the need for coordination between the contractor and subcontractors $\left(\mathrm{EC}_{2}\right)$. So the contractor should concern variations in coordination needs constantly. 
As the heart monitors blood pressure, the contractor should assign an engineer as a receptor to evaluate the balance between coordination needs and supply periodically according to environmental changes (item 3 ). In addition, because subcontractors are working hands-on on the project, they know about problems and changes earlier. They should be aware of variations in their coordination needs and inform the contractor, as organs do the heart, when the project is at the peak, design changes are issued, or accidents occur (item 4).

(3) Regulation. After receptors sense a change in blood pressure, the brain signals the heart to regulate blood flow via nerves or hormones. Similarly, when the contractor encounters an unusual condition or variation in coordination needs, he/she must adjust coordination supply and solve problems to keep the project on track. For instance, as the $\mathrm{EC}_{2}$ need increases, the contractor and subcontractors can discuss the issue through face-to-face or telephone discussions or the contractor can ask subcontractors to deliver an acceleration plan.

As the nervous system responds rapidly and hormones regulate blood flow chronically, the contractor adjusts coordination supply through informal and formal coordination methods as shown in Table 2 (items 5-7). When there are emergent conditions or accidents, the owner can coordinate through face-toface and telephone discussions in which participants can discuss and clarify causes and responsibilities immediately. When planned coordination supply does not meet needs, the contractor can make adjustments through formal methods such as revision of plans, increasing the frequency of meetings, and rescheduling tasks.

\section{Procedure for construction project effective coordination}

Based on the coordination system established above, a procedure for effective coordination in construction projects was developed to operationalize the system. The procedure as shown in Figure 3 consists of planning and execution stages and four steps. The steps in the planning stage are related to the normal condition of the coordination system, including coordination need evaluation and the supply of coordination based on needs; the steps in the execution stage include monitoring and regulation, which includes comparing coordination needs with supply and adjusting the coordination supply accordingly. Figure 3 also shows who is in charge of the work at each step:

(1) Evaluate the coordination needs before a project starts. Before the project starts, U\&E of a project should be assessed and the coordination needs of $\mathrm{EC}_{1}, \mathrm{IC}, \mathrm{EC}_{2}$, and IW are then derived using the U\&E questionnaire (see Appendix 1). The contractor's project manager or superintendent can conduct the assessment because they know the project better than other participants.

The U\&E questionnaire, developed by Chang and Tien (2006) according to information processing theory, encompasses five U\&E sources: task characteristics, task interdependence, human characteristics, task environment, and task-possessed information. There are 30 questions in total and each source accounts for six questions, with the first three questions assessing uncertainty and last three assessing equivocality. The questionnaire was used on design projects.

The method for allocating the five sources of the $\mathrm{U} \& \mathrm{E}$ to the needs of $\mathrm{EC}_{1}, \mathrm{IC}, \mathrm{EC}_{2}$, and IW is presented in Table 3, in which "+" represents accumulation and "-" represents deduction. The explanation for allocation rules was addressed in the research of Chang and Shen (2009).

(2) Arrange the coordination methods based on the assessment of the coordination needs. According to the needs of $\mathrm{EC}_{1}, \mathrm{IC}, \mathrm{EC}_{2}$, and IW evaluated in step (1), time spent on the nine methods is allocated by referring to Figure 2. E is higher than $\mathrm{U}$, which means that more coordination with the owner, internal members, and subcontractors is required, and more time will have to be spent on oral communication than written communication. For example, when $\mathrm{EC}_{1}$ receives a higher score, more meetings with the owner must be arranged. The contractor's project manager or superintendent can assign an engineer to analyze the project's U\&E and plan the frequency of, time spent on, nine coordination methods.

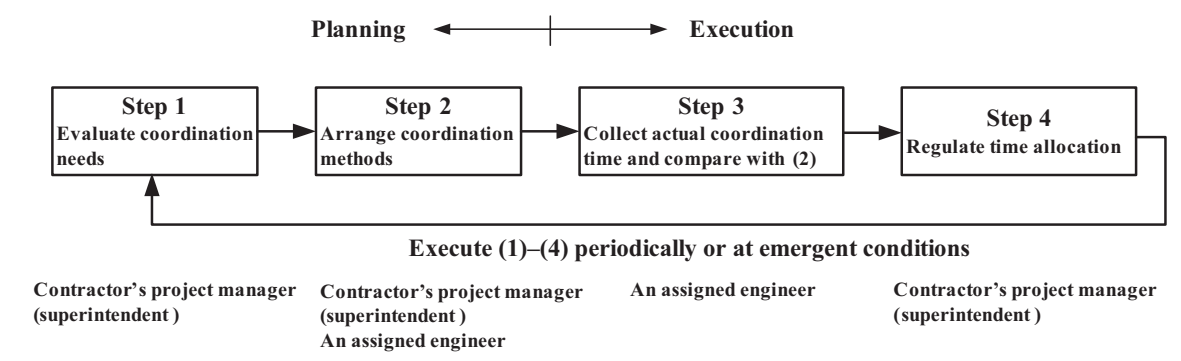

Fig. 3. Procedure for effective coordination 


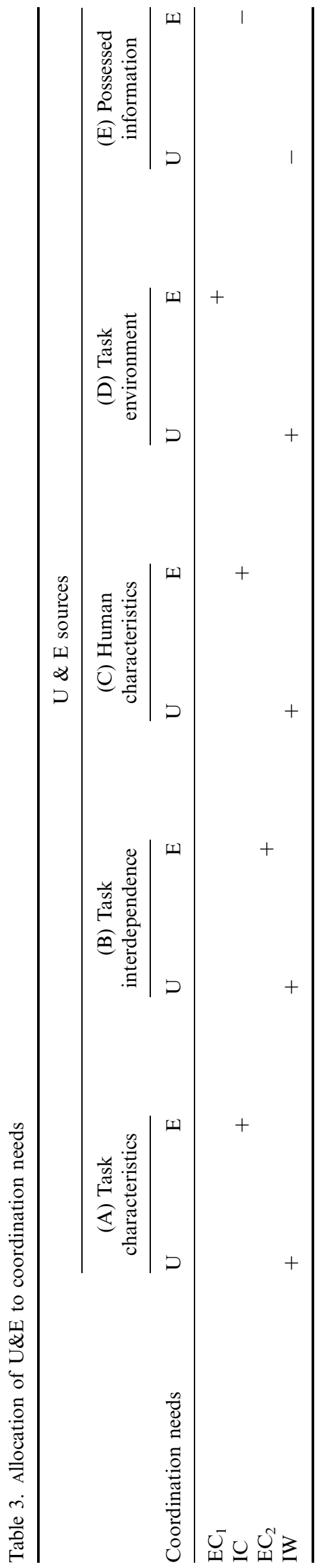

(3) Collect the actual time spent on the nine methods and compare with the planned time. During construction, the contractor assigns an engineer to survey the amounts of time regularly spent by engineers on the nine coordination methods by reviewing the time sheet (Appendix 2) and classifies them as $\mathrm{EC}_{1}, \mathrm{IC}, \mathrm{EC}_{2}$, and IW. Then, the actual times spent on $\mathrm{EC}_{1}, \mathrm{IC}, \mathrm{EC}_{2}$, and IW are compared with the amounts planned.

(4) Regulate time allocation when necessary. Actual time is compared with planned time for discrepancies. If coordination supply does not meet needs, the time spent on coordination methods need to be regulated. For example, if the time spent on $\mathrm{EC}_{1}$ is more than required, the contractor can reduce the frequency of meetings with the owner or the length of site visits. When the supply of IW is less than required, time spent on written correspondence, plans, schedules, reports, or contract documents should be increased. The project manager or superintendent regulates the frequency of, time spent on, nine coordination methods based on the result of step 3.

When the project goes smoothly, all steps (1-4) are executed at the peak and completion stage, which occur when the project is about $40 \%$ and $80 \%$ complete, respectively. However, when the project does not go smoothly, steps (1-4) are executed periodically (such as every 3 months) or at $10 \%$ progress increments. Coordination is continually planned and executed until the project is completed.

\section{Application through a case study}

To illustrate how the coordination system and procedure can be applied practically, an ongoing road construction project was tested. The project included a $1500 \mathrm{~m}$ road, ditches, a bridge, and landscape engineering. It had duration of 240 work days and a contract price of US\$ 4.4 million. The contractor's project team consisted of a project manager, a superintendent, two site engineers, and two staffs. The method for using the four steps of the procedure is explained as follows:

(1) Evaluate coordination needs. Tasks executed during the first month included building a retaining wall, ground treatment, and installation of underpass drains. The superintendent evaluated the three tasks' U\&E separately. The scores given to each question are shown in Table 4. As Table 4 shows, ground treatment received a higher $U$ score (33) and the installation of underpass drain received a higher E score (25). The average U\&E scores of 27.8 and 20.2, respectively, represent the project $U \& E$, meaning there was greater uncertainty than equivocality. 
Table 4. Tasks' U\&E in the first month

\begin{tabular}{|c|c|c|c|c|c|c|c|c|c|c|}
\hline \multirow[b]{2}{*}{$\mathrm{U} \& \mathrm{E}$ dimension } & \multicolumn{2}{|c|}{ Retaining wall } & \multicolumn{2}{|c|}{$\begin{array}{l}\text { Ground } \\
\text { treatment }\end{array}$} & \multicolumn{2}{|c|}{$\begin{array}{c}\text { Underpass } \\
\text { drain }\end{array}$} & \multicolumn{2}{|c|}{ Average } & \multicolumn{2}{|c|}{ Summary } \\
\hline & Q1-Q3 & Q4-Q6 & Q1-Q3 & Q4-Q6 & Q1-Q3 & Q4-Q6 & Q1-Q3 & Q4-Q6 & Q1-Q3 & Q4-Q6 \\
\hline \multirow[t]{3}{*}{ (A) Task characteristics } & 2 & 2 & 4 & 2 & 3 & 3 & 3.0 & 2.3 & \multirow[t]{3}{*}{8.7} & \multirow[t]{3}{*}{7.3} \\
\hline & 4 & 2 & 3 & 3 & 2 & 3 & 3.0 & 2.7 & & \\
\hline & 2 & 2 & 4 & 3 & 2 & 2 & 2.7 & 2.3 & & \\
\hline \multirow{3}{*}{ (B) Task interdependence } & 5 & 2 & 5 & 2 & 4 & 3 & 4.7 & 2.3 & \multirow[t]{3}{*}{10.4} & \multirow[t]{3}{*}{7.0} \\
\hline & 2 & 1 & 3 & 3 & 3 & 2 & 2.7 & 2.0 & & \\
\hline & 2 & 2 & 4 & 3 & 3 & 3 & 3.0 & 2.7 & & \\
\hline \multirow[t]{3}{*}{ (C) Human characteristics } & 3 & 5 & 3 & 4 & 3 & 3 & 3.0 & 4.0 & \multirow[t]{3}{*}{11.0} & \multirow[t]{3}{*}{8.0} \\
\hline & 3 & 2 & 3 & 2 & 3 & 3 & 3.0 & 2.3 & & \\
\hline & 5 & 1 & 5 & 1 & 5 & 3 & 5.0 & 1.7 & & \\
\hline \multirow[t]{3}{*}{ (D) Task environment } & 3 & 2 & 3 & 2 & 2 & 3 & 2.7 & 2.3 & \multirow[t]{3}{*}{8.0} & \multirow[t]{3}{*}{7.3} \\
\hline & 3 & 2 & 3 & 2 & 3 & 3 & 3.0 & 2.3 & & \\
\hline & 2 & 1 & 2 & 4 & 3 & 3 & 2.3 & 2.7 & & \\
\hline \multirow[t]{3}{*}{ (E) Task-possessed information } & 3 & 3 & 3 & 2 & 4 & 3 & 3.3 & 2.7 & \multirow[t]{3}{*}{10.3} & \multirow[t]{3}{*}{9.4} \\
\hline & 2 & 3 & 3 & 3 & 3 & 3 & 2.7 & 3.0 & & \\
\hline & 5 & 4 & 3 & 4 & 5 & 3 & 4.3 & 3.7 & & \\
\hline $\mathrm{U}$ & 26 & 33 & 24 & 27.8 & 48.0 & & & & & \\
\hline $\mathrm{E}$ & 14 & 22 & 25 & 20.2 & & & & & & \\
\hline
\end{tabular}

The U\&E scores were allocated to the needs of $\mathrm{EC}_{1}, \mathrm{IC}, \mathrm{EC}_{2}$, and IW according to rules in Table 3:

$$
\begin{aligned}
& \mathrm{EC}_{1}=7.3(\mathrm{Q} 4-\mathrm{Q} 6 \text { of } \mathrm{D}) ; \\
& \mathrm{IC}=7.3+8.0-9.4=5.9(\mathrm{Q} 4-\mathrm{Q} 6 \text { of }(\mathrm{A}+\mathrm{C}-\mathrm{E})) \\
& \mathrm{EC}_{2}=7.0(\mathrm{Q} 4-\mathrm{Q} 6 \text { of } \mathrm{B}) ; \text { and } \\
& \mathrm{IW}=8.7+10.4+11+8-10.3=27.8
\end{aligned}
$$$$
(\mathrm{Q} 1-\mathrm{Q} 3 \text { of }(\mathrm{A}+\mathrm{B}+\mathrm{C}+\mathrm{D}-\mathrm{E})) \text {. }
$$

Thus the need for IW was higher (27.8), followed by the coordination needs of the owner $\left(\mathrm{EC}_{1}\right)$ and subcontractors $\left(\mathrm{EC}_{2}\right)(7.3,7)$. The need for $\mathrm{IC}$ was lower, with the score of 5.9 .

(2) Arrange the coordination methods. Time spent on the nine methods was planned based on the scores of $\mathrm{EC}_{1}, \mathrm{IC}, \mathrm{EC}_{2}$, and IW in step (1). Assume that an engineer works for 10 hours per day. Then the time spent on $\mathrm{EC}_{1}=10 * 7.3 /(7.3+5.9+7+27.7)=1.5 ; \quad \mathrm{IC}=1.2$; $\mathrm{EC}_{2}=1.5$ and $\mathrm{IW}=5.8 \mathrm{hr}$. The contractor can arrange weekly meetings and use face-to-face and telephone discussions or site visits to fulfill the needs of $\mathrm{EC}_{1}, \mathrm{IC}$, and EC2. In addition, engineers should spend more time (roughly $5.8 \mathrm{hr} /$ day) writing plans, arranging schedules, and clarifying contract clauses during the initial stage of the project.

(3) Collect the actual amount of time spent on the nine coordination methods. During construction, the contractor used the time sheet (Appendix 2) to collect time spent on the nine methods by the six engineers. Time percentages of the nine methods are presented in Table 5. The most time was spent on site visits $(1+9.9+21.6=32.5 \%)$, followed by written correspondence $(31 \%)$.
Time spent on $\mathrm{EC}_{1}, \mathrm{IC}, \mathrm{EC}_{2}$, and $\mathrm{IW}$ was calculated according to Figure 2:

$$
\begin{aligned}
& \mathrm{EC}_{1}=0.3+2.8+1=4.1 \% \\
& \mathrm{IC}=0.2+7.1=7.3 \% \\
& \mathrm{EC}_{2}=1+7.6+9.9=18.5 \% ; \text { and } \\
& \mathrm{IW}=21.6+31+3.2+4.5+2.9+6.9=70.1 \%
\end{aligned}
$$

Thus the project team spent more time on IW $(70.1 \%)$, followed by coordination with subcontractors and suppliers $(18.5 \%)$. Coordination with the owner accounted for less work time (4.1\%).

(4) Regulate time allocation. Table 6 shows coordination time percentages from step (3) and coordination need percentages from step (1). As Table 6 shows, the coordination supply of $\mathrm{EC}_{2}$ and IW (18.5, $70.1)$ in the first month exceeded their needs $(15,58)$. This means that too much time was spent on solo visits and written communication methods and should be reduced. The coordination supply of $\mathrm{EC}_{1}$ and IC $(4.1,7.3)$ was less than their needs $(15,12)$, meaning the contractor should coordinate work with the owner and internal members using methods such as meetings more often.

In the second month, the contractor evaluated the U\&E of tasks, including ditch building, retaining wall building, installation of underpass drain, ditch grating covering, grating and foundation improvement, and coordination time allocation. As Table 6 shows, the four needs varied little but the coordination supply was different compared with those in the first month. The contractor regulated their time spent on $\mathrm{EC}_{1}, \mathrm{IC}, \mathrm{EC}_{2}$, and IW. Time spent on $\mathrm{EC}_{1}$ and $\mathrm{IC}$ was 
Table 5. Coordination time allocation of the case project

\begin{tabular}{|c|c|c|c|c|c|c|c|c|c|}
\hline Coordination methods & & PM & Superintendent & Site engineer & Site engineer & Staff & Staff & Total (hr) & $\%$ \\
\hline \multirow[t]{3}{*}{ 1. Meetings } & Owner & 0 & 1 & 0 & 0 & 0 & 0 & 1 & 0.3 \\
\hline & Internal & 0 & 0.5 & 0 & 0 & 0 & 0 & 0.5 & 0.2 \\
\hline & Subcontractor & 0 & 3 & 0 & 0 & 0 & 0 & 3 & 1 \\
\hline \multirow[t]{3}{*}{ 2. Telephone $\&$ face to face } & Owner & 0 & 6.5 & 1 & 0 & 1 & 0 & 8.5 & 2.8 \\
\hline & Internal & 0 & 9 & 4 & 0 & 6 & 3 & 22 & 7.1 \\
\hline & Subcontractor & 6 & 3.5 & 14 & 0 & 0 & 0 & 23.5 & 7.6 \\
\hline \multirow[t]{3}{*}{ 3. Site visits } & Owner & 0 & 1 & 2 & 0 & 0 & 0 & 3 & 1 \\
\hline & Subcontractor & 18 & 6.5 & 6 & 0 & 0 & 0 & 30.5 & 9.9 \\
\hline & alone & 24 & 15.5 & 27 & 0 & 0 & 0 & 66.5 & 21.6 \\
\hline 4. Written correspondence & & 0 & 6.5 & 0 & 60 & 18 & 11 & 95.5 & 31 \\
\hline 5. Plans & & 0 & 1 & 0 & 0 & 9 & 0 & 10 & 3.2 \\
\hline 6. Schedules & & 0 & 3 & 0 & 0 & 5 & 6 & 14 & 4.5 \\
\hline 7. Reports & & 0 & 2 & 6 & 0 & 1 & 0 & 9 & 2.9 \\
\hline 8. Contract documents & & 0 & 1 & 0 & 0 & 0 & 20 & 21 & 6.9 \\
\hline Total & & 48 & 60 & 60 & 60 & 40 & 40 & 308 & 100 \\
\hline
\end{tabular}

increased from $4.1 \%$ and $7.3 \%$ to $8 \%$ and $13 \%$, respectively; time spent on $\mathrm{EC}_{2}$ and IW was reduced from $18.5 \%$ and $70.1 \%$ to $13 \%$ and $66 \%$, respectively.

The coordination was then better supplied in accordance with the coordination needs in the second month, especially in IC and $\mathrm{EC}_{2}$, with the variance of $2 \%$ and $1 \%$, respectively. The contractor spent an adequate amount of time on coordination with internal members and subcontractors, but inadequate time with owners and internal work. It appeared that the contractor could work well with internal members and subcontractors and regulate the coordination methods. Some $\mathrm{EC}_{1}$ and IW were resulted from the owner such as meetings, plans, and written correspondence that could not be controlled by the contractor. But the contractor should try to decrease discrepancies between coordination supply and needs of $\mathrm{EC}_{1}$ and IW.

\section{Discussions}

The coordination system used in construction resembles the circulatory system of the human body from the perspective of function and operation. Because human body physiology is very complicated and effective, this study simplified some mechanisms to apply the functions of the circulatory system to project coordination.

First, the individual coordination need with subcontractors and suppliers was combined together as $\mathrm{EC}_{2}$, whereas each organ in the body has its own blood flow. Every organ, such as the lungs, stomach, liver, and intestines, is important and has its own blood requirements. To simplify the coordination system and make evaluation easy, $\mathrm{EC}_{2}$ includes coordination with all subcontractors and suppliers, such as steel suppliers, concrete subcontractors, and workmen. This may cause system to meet the total needs of $\mathrm{EC}_{2}$, not necessarily that of each subcontractor or supplier. So time spent on coordination with some subcontractors may be excessive, while that spent with others may be insufficient.

Second, in addition to blood pressure, receptors also detect substance changes in blood, which is not considered in this study. The substances carried by the blood could be compared to coordination quality, which includes the utility and clarity of communication between participants of a coordination method. Highquality coordination methods help communicators to achieve their goals effectively. Future research could incorporate coordination quality into the coordination system and procedure to make it more complete.

Third, the function of the owner in construction projects is not as prominent as the brain of the human body. The brain regulates blood flow through the signals sent via nerves and hormones when necessary. But in construction projects, the contractor is in charge of project execution and management and

Table 6. Coordination needs and supply of the case project

\begin{tabular}{|c|c|c|c|c|c|c|}
\hline \multirow[b]{2}{*}{ Type } & \multicolumn{3}{|c|}{ The first month } & \multicolumn{3}{|c|}{ The second month } \\
\hline & Need $(\%)$ & Supply (\%) & Variance $(\%)$ & Need $(\%)$ & Supply $(\%)$ & Variance $(\%)$ \\
\hline $\mathrm{EC}_{1}$ & 15 & 4.1 & 10.9 & 15 & 8 & 7 \\
\hline IC & 12 & 7.3 & 4.7 & 15 & 13 & 2 \\
\hline $\mathrm{EC}_{2}$ & 15 & 18.5 & 3.5 & 14 & 13 & 1 \\
\hline IW & 58 & 70.1 & 12.1 & 56 & 66 & 10 \\
\hline Total & 100 & 100 & - & 100 & 100 & - \\
\hline
\end{tabular}


takes more responsibility for project failure than the owner. The owner often regulates coordination with the contractor forcibly during emergent conditions or when the contractor violates the contract. So the owner is not as important to the coordination system as the brain is to the circulatory system.

The coordination system can be used on projects with different delivery methods although it was implicitly developed based on the traditional designbid-build (DBB) method. The relations and amount of interaction between the contractor and other project participants may vary due to the change of the parties' roles in projects. In a DBB project, the contractor mainly coordinates work with the owner and designer $\left(\mathrm{EC}_{1}\right)$, internal members (IC), and subcontractors and suppliers $\left(E_{2}\right)$, as mentioned in the section 2 . Compared with those in a DBB project, the coordination needs or amount of $\mathrm{EC}_{1}, \mathrm{IC}$, and $\mathrm{EC}_{2}$ may vary in projects using other delivery methods. For example, when a project is awarded using the multiple prime contractor method, each contractor is the heart of his or her project. The coordination need of a contractor with others $\left(\mathrm{EC}_{1}\right)$ increases because the owner would ask contractors to coordinate with each other to consider the project as a whole (Rojas 2008).

In a design-build project, the design-builder is the heart of the project. The designer may act like an internal member or a subcontractor of the contractor instead of a representative of the owner in a DBB project. The coordination amount of the designbuilder with the owner $\left(\mathrm{EC}_{1}\right)$ decreases but the coordination amount with internal members (IC) or subcontractors $\left(\mathrm{EC}_{2}\right)$ increases (Gould, Joyce 2008). As for a project using construction manager at risk $(\mathrm{CM} @ \mathrm{R})$, the owner contracts with a single entity to provide construction management services during design, who then provides labor, material, and project management during construction as a general contractor (Cunningham 2005). The CM@R plays the role of the heart at the construction stage. The coordination need of the $\mathrm{CM} @ \mathrm{R}$ with the owner and designer $\left(\mathrm{EC}_{1}\right)$ decreases because he or she participates in the project at the design stage. He or she better understands owner's requirements and design errors and omissions can be reduced (Rojas, Kell 2008). The IC need of the CM@R may also decrease because the project team has coordinated construction work since the design stage.

Moreover, the procedure with four steps for effective coordination in construction projects was established to apply the coordination system practically. The contractor could assign an engineer as a receptor who surveys time spent on coordination methods. But how to evaluate a project's $U \& E$ and the coordination needs of $\mathrm{EC}_{1}, \mathrm{IC}, \mathrm{EC}_{2}$, and IW needs seems problematic. This study used the U\&E questionnaire proposed by Chang and Tien (2006) to test the applicability of the proposed system and procedure. Future research can develop a method to evaluate $U \& E$ of construction projects or use other present tools.

\section{Conclusions}

Effective coordination is critical to the success of construction projects. Most engineers coordinate their work using meetings, plans, and contract documents out of convenience or preference rather than effectiveness, yet project performance often does not meet expectations. A systematic method is necessary to help construction project organizations coordinate work effectively.

A coordination system for construction projects was developed by simulating the circulatory system of the human body. The coordination system could be helpful because functions and operations of the circulatory system are natural and effective. As for main characters comparisons, the contractor is like the heart, the owner is like the brain, and subcontractors and suppliers are like the various organs. Coordination needs derived from project U\&E are mainly categorized into $\mathrm{EC}_{1}, \mathrm{IC}, \mathrm{EC}_{2}$, and IW as each organ has its own blood requirements. Coordination is supplied by engineers through different methods as nutrients are transported by blood flow and vessels. The matching of coordination supply to coordination needs could result in better project performance. So contractors should assign an engineer as detector to evaluate the appropriateness of time spent on coordination with relevant parties and make adjustments when necessary.

This paper also provides a procedure for effective coordination in construction projects to apply the coordination system practically. The procedure is divided into planning and execution stages with four steps. In the planning stage, the coordination needs of $\mathrm{EC}_{1}, \mathrm{EC}_{2}, \mathrm{IC}$, and IW are evaluated and coordination methods are arranged based on each need. During execution, time spent on coordination methods is collected to identify discrepancies. Time spent on coordination methods is then adjusted and improved. Coordination is continually planned and executed until a project is completed.

The proposed coordination system and procedure were applicable through an illustration of a case project. Future research can apply the system and procedure on construction projects, from beginning to completion, to test their contributions to project performance.

\section{References}

Adriaanse, A.; Voordijk, H.; Dewulf, G. 2010. Adoption and use of interorganizational ICT in a construction project, Journal of Construction Engineering and Management ASCE 136(9): 1003-1014. http://dx.doi.org/10.1061/(ASCE)CO.1943-7862. 0000201 
ASCE. 2000. Quality in the constructed project: a guide for owners, designers and constructors. 2nd ed. Virginia: American Society of Civil Engineers. 266 p.

Carlson, P. J.; Davis, G. B. 1998. An investigation of media selection among directors and managers: from self to other orientation, MIS Quarterly 22(3): 335-362. http://dx.doi.org/10.2307/249669

Carlson, J. R.; Zmud, R. W. 1999. Channel expansion theory and the experiential nature of media richness perceptions, Academy of Management Journal 42(2): 153170. http://dx.doi.org/10.2307/257090

Chang, A. S. 2001. Work time model for engineers, Journal of Construction Engineering and Management ASCE 127(2): 163-172.

http://dx.doi.org/10.1061/(ASCE)0733-9364(2001) 127:2(163)

Chang, A. S.; Shen, F. Y. 2009. Coordination needs and supply of construction projects, Engineering Management Journal 21(4): 44-57.

Chang, A. S.; Tien, C.-C. 2006. Quantifying uncertainty and equivocality in engineering projects, Construction Management and Economics 24(2): 171-184. http://dx.doi.org/10.1080/01446190500310353

Cunningham, G. 2005. Commissioning large public projects using construction manager at risk (CMR), in National Conference on Building Commissioning, 2005, New York, USA: Building Commissioning Association, $1-14$.

Daft, R. L. 2004. Organization theory and design. 8th ed. Mason, Ohio: South-Western Publishing Company. 672 p.

Daft, R. L.; Lengel, R. H. 1986. Organizational information requirements, media richness and structural design, Management Science 32(5): 554-571. http://dx.doi.org/10.1287/mnsc.32.5.554

Daft, R. L.; Macintosh, N. B. 1981. A tentative exploration into the amount and equivocality of information processing in organizational work units, Administrative Science Quarterly 26(2): 207-224. http://dx.doi.org/10.2307/2392469

Dennis, A. R.; Fuller, R. M.; Valacich, J. S. 2008. Media, tasks, and communication processes: a theory of media synchronicity, MIS Quarterly 32(3): 575-600.

Enshassi, A.; Mohamed, S.; Abushaban, S. 2009. Factors affecting the performance of construction projects in the Gaza Strip, Journal of Civil Engineering and Management 15(3): 269-280. http://dx.doi.org/10.3846/1392-3730.2009.15.269-280

Forrester, R.; Drexler, A. B. 1999. A model for team-based organization performance, Academy of Management Executive 13(3): 36-49.

Gabrielaitis, L.; Baušys, R. 2006. Electronic document management in building design, Journal of Civil Engineering and Management 12(2): 103-108.

Gould, F. E.; Joyce, N. E. 2008. Construction project management. 3rd ed. New Jersey: Prentice Hall. 384 p.

Jha, K. N.; Iyer, K. C. 2006. Critical determinants of project coordination, International Journal of Project Management 24(4): 314-322.

http://dx.doi.org/10.1016/j.ijproman.2005.11.005

Kock, N. 2004. The psychobiological model: towards a new theory of computer-mediated communication based on Darwinian evolution, Organization Science 15(3): 327-348.

http://dx.doi.org/10.1287/orsc.1040.0071

Leite, F.; Akcamete, A.; Akinci, B.; Atasoy, G.; Kiziltas, S. 2011. Analysis of modeling effort and impact of different levels of detail in building information models, Automation in Construction 20(5): 601-609. http://dx.doi.org/10.1016/j.autcon.2010.11.027

Lengel, R. H.; Daft, R. L. 1989. The selection of communication media as an executive skill, The Academy of Management Executive 2(3): 225-232. http://dx.doi.org/10.5465/AME.1988.4277259

Malone, T. W.; Crowston, K. 1994. The interdisciplinary study of coordination, ACM Computing Surveys 26(1): 87-119. http://dx.doi.org/10.1145/174666.174668

Okhuysen, G. A.; Bechky, B. A. 2009. Coordination in organizations: an integrative perspective, The Academy of Management Annals 3(1): 463-502. http://dx.doi.org/10.1080/19416520903047533

Patrashkova-Volzdoska, R. R.; McComb, S. A.; Green, S. G.; Compton, W. D. 2003. Examining a curvilinear relationship between communication frequency and team performance in cross-functional project teams, IEEE Transactions on Engineering Management 50(3): 262269. http://dx.doi.org/10.1109/TEM.2003.817298

Pocock, J. B.; Hyun, C. T.; Liu, L. Y.; Kim, M. K. 1996. Relationship between project interaction and performance indicators, Journal of Construction Engineering and Management ASCE 122(2): 165-176.

http://dx.doi.org/10.1061/(ASCE)0733-9364(1996) 122:2(165)

Rojas, E. M. 2008. Single versus multiple prime contracting, Journal of Construction Engineering and Management ASCE 134(10): 758-765.

http://dx.doi.org/10.1061/(ASCE)0733-9364(2008) 134:10(758)

Rojas, E. M.; Kell, I. 2008. Comparative analysis of project delivery systems cost performance in Pacific Northwest public schools, Journal of Construction Engineering and Management ASCE 134(6): 387-397.

http://dx.doi.org/10.1061/(ASCE)0733-9364(2008) 134:6(387)

Seeley, R. R.; Stephens, T. D.; Tate, P. 2003. Anatomy and physiology. 6th ed. Boston: McGraw-Hill. 1110 p.

Shen, F. Y. 2009. Establishing coordination model and operation mechanisms for construction projects. $\mathrm{PhD}$ Dissertation. Taiwan: National Cheng Kung University (in Chinese).

Sherwood, L. 2007. Human physiology: from cells to systems. 6th ed. Belmont, CA: Thomson Brooks/Cole. 928 p.

Thomas, S. R.; Tucker, R. L.; Kelly, W. R. 1998. Critical communications variables, Journal of Construction Engineering and Management ASCE 124(1): 58-66. http://dx.doi.org/10.1061/(ASCE)0733-9364(1998) 124:1(58)

Webster, J.; Trevino, L. K. 1995. Rational and social theories as complementary explanations of communication media choices: two policy-capturing studies, Academy of Management Journal 38(6): 1544-1572. http://dx.doi.org/10.2307/256843 
Wiesenfeld, B. M.; Raghuram, S.; Garud, R. 1999. Communication patterns as determinants of organizational identification in a virtual organization, Organization Science 10(6): 777-790. http://dx.doi.org/10.1287/orsc. 10.6.777

Yang, J.; Shen, G. Q.; Ho, M.; Drew, D. S.; Chan, A. P. C. 2009. Exploring critical success factors for stakeholder management in construction projects, Journal of Civil

\section{Appendix 1: Uncertainty and Equivocality Assessment Questionnaire}

\section{Task characteristics}

\subsection{Task variability}

1. How different are the situations, problems, or issues you expect to encounter while performing this task? (1) Almost the same (2) Mostly the same (3) Similar (4) Somewhat different (5) Different;

2. During a normal month, how frequently are exceptions expected to arise while doing this task? (1) Infrequently (2) (3) (4) (5) Frequently; and

3. How often are the same work methods or steps followed while doing the task? (1) Seldom - (5) Often.

\subsection{Task difficulty}

1. To what extent is this task analyzable? (1) High (5) Low;

2. How easy is it to know whether this task was done correctly? (1) Easy - (5) Difficult; and

3. What is the possibility of difficult problems arising in which there will be no immediate or apparent solutions while performing this task? (1) Low - (5) High.

\section{Task interdependence}

\subsection{Workflow}

1. Please indicate the workflow pattern between project members while performing this task. (1) Independent (2) Light sequential (3) Heavy sequential (4) Light reciprocal (5) Heavy reciprocal;

2. How much does this task depend on others to obtain resources and/or information? (1) Little (5) Much; and

3. How much do other tasks depend on this task's output to do their work? (1) Little - (5) Much.

\subsection{Differences between related tasks}

1. How different are the required reporting and control procedures between this task and its related tasks? (1) Same - (5) Different;
Engineering and Management 15(4): 337-348. http://dx.doi.org/10.3846/1392-3730.2009.15.337-348

Zack, M. H. 1993. Interactivity and communication mode choice in ongoing management groups, Information Systems Research 4(3): 207-239. http://dx.doi.org/10. 1287/isre.4.3.207

2. How often is the interface between this task and its related tasks overlooked? (1) Seldom - (5) Often;

3. To what extent do you expect interruptions to the workflow encountered while performing this task? (1) Low - (5) High.

\section{Human characteristics}

\subsection{Individual capability}

1. What is the average experience of members who perform this task? (1) More than 20 years (2) 15-20 years (3) 10-15 years (4) 5-10 years (5) less than 5 years;

2. How much experience do the task performers have prior on similar tasks? (1) Much - (5) Little; and

3. What are the abilities and education levels of the members who perform this task? (1) Excellent (5) Below average.

\subsection{Differences between individuals}

1. How long have the task performers been working at the company? (1) More than 20 years (2) 15-20 years (3) 10-5 years (4) 5-10 years (5) less than 5 years;

2. How different are the task performers' attitudes and behaviors in terms of goals, time, and interpersonal orientations? (1) Almost the same - (5) Very different; and

3. How often do you expect disagreements or conflicts to occur among project members while performing this task? (1) Seldom - (5) Often.

\section{Task environment}

\subsection{Quantitative environment}

1. How important is this task (e.g. on the critical path)? (1) Few - (5) Many;

2. How much time does this task need to await while performing this task and its related tasks? (1) Little - (5) Much; and

3 . How is the morale of this task performing group? (1) High - (5) Low.

\subsection{Qualitative environment}

1. How many times does the task need interpretations to government agencies or other stakeholders while performing this task? (1) Few - (5) Many; 
2. How different are the required reporting and control procedures between intra-project and extra-project for performing this task? (1) Same (5) Different; and

3. How often do you expect disagreement or conflict between intra-project and extra-project participants while performing this task? (1) Seldom (5) Often.

\section{Task-possessed information}

\subsection{Amount of possessed information}

1. How much similar experience does the company have performing the task? (1) Little - (5) Much;
2. How much time was spent on planning or preparing this task? (1) Little - (5) Much; and

3. How much error is there in the estimated cost and time for this task? (1) $>50 \%$ (2) $40 \%$ (3) $20 \%$ (4) $10 \%(5)<5 \%$.

\subsection{Quality of possessed information}

1. To what extent is the information about this task reliable? (1) Low - (5) High;

2. How many inconsistencies and conflicts are there in the information about this task? (1) Many (5) Few; and

3. To what extent are the task's goals and needs clear to performers? (1) Low - (5) High.

\section{Appendix 2: Work time distribution sheet}

Please write down the numbers of your coordination methods listing below while working for a week. For example: write 1.1 while attending the meeting with the owner; write 2.3 while talking with the subcontractor by phone.

Project Name: $\longrightarrow$ Progress: about $\_\%$,
Date: $\_$Filler's Position: $\_$: Top___ Middle___ Bot-
tom_ level of the project organization.

Monday Tuesday Wednesday Thursday $\quad$ Friday Saturday

Morning 8:00 9:00

9:00 10:00

10:00 11:00

$11: 00 \sim 12: 00$

Afternoon 1:00 2:00

2:00 3:00

$3: 00 \sim 4: 00$

$4: 00 \sim 5: 00$

$5: 00 \sim 6: 00$

$6: 00 \sim 7: 00$

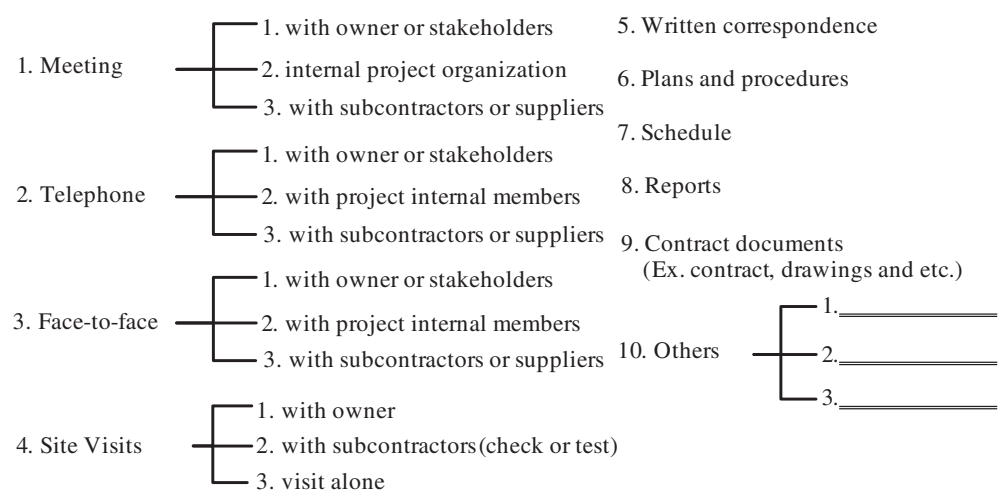

Fang-Ying SHEN. Postdoctoral fellow of Civil Engineering Department of National Cheng Kung University in Taiwan. She has ten years of experience on design and construction projects. She received a PhD from National Cheng Kung University, and is a PMP and registered professional engineer in Taiwan.

Andrew S. CHANG. Professor of Civil Engineering Department of National Cheng Kung University in Taiwan. He has over twelve years of project control experience on large engineering and construction projects. He received a PhD from the University of California at Berkeley, and is a registered professional engineer in California. 